Canadian Journal of Fisheries and Aquatic Sciences

November 2008 ; Volume 65 (11) : Pages 2444-2453

http://dx.doi.org/10.1139/F08-147

(c) 2008 NRC Canada
Archimer http://www.ifremer.fr/docelec/ Archive Institutionnelle de l'Ifremer

The original publication is available at http://pubs.nrc-cnrc.gc.ca

\title{
A dynamic model of the Bay of Biscay pelagic fleet simulating fishing trip choice: the response to the closure of the European anchovy (Engraulis encrasicolus) fishery in 2005
}

\author{
Youen Vermard $^{1,2,{ }^{*},+}$, Paul Marchal $^{1}$, Stéphanie Mahévas ${ }^{2}$, Olivier Thébaud $^{3}$ \\ ${ }^{1}$ IFREMER- Département Halieutique de Manche-Mer du Nord,150 Quai Gambetta, BP 699, 62321 Boulogne \\ s/mer, France. \\ ${ }^{2}$ IFREMER- Département Ecologie et Models pour l'halieutique, Rue de l'lle d'Yeu, BP 21105, 44311 Nantes \\ Cedex 03, France. \\ ${ }^{3}$ IFREMER- UMR AMURE, B.P. 70, 29280 Plouzané, France. \\ ${ }^{+}$Present address: Agrocampus Rennes Pôle halieutique, 65 rue de Saint-Brieuc, CS 84215, 35042 Rennes \\ cedex, France. Tél. : 33 (0)2 23485536 - Fax : 33 (0)2 23485535
}

*: Corresponding author : Youen Vermard, email address : Youen.Vermard@ifremer.fr

\begin{abstract}
The scope of this paper is to describe, evaluate, and forecast fishing trip choices of the Bay of Biscay pelagic fleet using random utility modeling (RUM). First, alternative fishing trip choices of this fleet were identified using multivariate statistical methods based on species landings weighted by value and defined as distinct fishing activity or fisheries (termed métiers). A RUM was specified, which included trip components as attributes during the period 2001-2004 (a lagged percentage of the value per unit of effort of the main species caught, total value per unit of effort, and inertia in terms of changes from one métier to another). For the main métiers, the proportion of correct effort allocation is $90 \%$ during the calibration period of 2001-2004. The results from the RUM are used to parameterize a simulation model of trip choice. The model is used to predict trip choices in 2005, throughout most of which fishing was constrained by the closure of the European anchovy (Engraulis encrasicolus) fishery. Simulation results are compared with observed trip choices following the fishing ban: $80 \%$ of observed trip choices are correctly predicted by the model. The capacity of the behavioral model to predict responses to the closure is then discussed.
\end{abstract}

Résumé : Cet article a pour objectif de décrire, d'évaluer et de prédire le choix de l'activité de pêche à l'échelle de la marée pour les chalutiers pélagiques du Golfe de Gascogne en utilisant des modèles de choix discrets (RUM, « random utility modeling »). Les pratiques alternatives ont été identifiées par des méthodes statistiques multivariées basées sur les débarquements spécifiques en valeur et ont été définies comme autant de pratiques nommées par la suite métiers. Un RUM a été spécifié incluant les caractéristiques de la marée (le pourcentage de la valeur par unité d'effort (VPUE) des espèces principales capturées et la VPUE totale de la marée précédente ainsi que l'inertie pour changer de métier) comme attributs durant la période 2001-2004. Pour les métiers principaux, le modèle est capable de prédire correctement $90 \%$ des choix observés durant la période de calibration. Nous utilisons ensuite ces résultats pour paramètrer un modèle de simulation de choix d'activité. Le modèle a servi à prédire les choix en 2005, année au cours de laquelle un arrêt de pêche à l'anchois (Engraulis encrasicolus) a été imposé. Les résultats de la simulation sont comparés aux choix observés suite à la fermeture : $80 \%$ des choix de métiers observés sont correctement prédits par le modèle. La capacité du modèle à prédire la réponse à la fermeture fait ensuite l'objet d'une discussion.

Keywords: RUM, fisher's behavior, fishing effort, métier, management 


\section{Introduction}

In the current context of fisheries management simulation models are required to support the evaluation of management scenarios. These models should include the key processes of the fishery system: stock dynamics, fleet dynamics, manager decision-making, and the interactions between these three elements.

Most of the existing models have concentrated on the modeling of biological processes, population dynamics and ecosystem interactions (see Pelletier and Mahévas 2005 for a synthesis of the different models dealing with population and ecosystem modeling). However, as stressed by Hilborn (1985), a number of fisheries management failures could have resulted from a misunderstanding of fisher behavior, more than from limited knowledge of the status of fishery resources. Wilen et al. (2002) showed that in an exploited system, fishers' spatial behavior influences the predicted outcomes of management policies, just as importantly as biological and ecological factors.

Fisher behavior and the resultant fleet dynamics, can be seen at different scales that can be divided into long-, medium- and short-term. Long-term dynamics involve inter-annual investment behavior resulting in the entry-exit of vessels in and out of fisheries, and in technical creeping. Shortterm behavior involves the infra-annual choices made by fishing operators as regards, e.g., fishing gear to use in a given fishery. Very short term behavior can also be described, focusing on the sequence of decisions which are made at the scale of the fishing operation, e.g. selecting a particular fishing area at a given stage of a fishing trip.

In this paper we will focus on description of short term behavior and the choice of what we call a "métier" at the scale of the fishing trip. Describing short-term behavior helps in understanding the fishery system (Sala and Gaetner 2004). The processes driving micro-economic decisions in fisheries have already been modeled using several methods. Fisher behavior has been described using the gravity model of Caddy (1975), while others have applied the Ideal Free Distribution assumption, generalized linear or additive models, Random Utility Modeling or optimal foraging theory (see Pelletier and Mahévas 2005 and Prellezo et al. 2006 for review). Among these methods, Random Utility Modeling (RUM) is currently receiving particular attention, as it is specifically devoted to the modeling of discrete decisions by individual economic agent, thus incorporating a model of decision making directly based on economic theory (Wilen et al. 2002). Random Utility Modeling can be used to describe fisher's behavior using attributes and characteristics of the choices defined at the microeconomic level. This method was used, in particular, to describe fisher's location choice (Holland and Sutinen 1999, Smith and Wilen 2003, Hutton et al. 2005) or fisher's trip choice behavior as in Pradhan and Leung (2004).

In this paper Random Utility modeling is used to describe métier choices at the scale of the trip for the Bay of Biscay fleet of pelagic trawlers. The purpose of this research is to develop an empirical model that could be used to predict how changes in the catch rate of targeted species and in management regulations may influence fishers' behavior. Moreover this fleet is experiencing a severe crisis due to the closure of the anchovy fishery since 2005 . We thus aim to test the robustness of the behavioral model in terms of predicting the response of effort allocation to shifts in management regimes, including fishing bans such as the one that was experienced by this fleet.

The paper is structured as follows. After describing the background of the Bay of Biscay pelagic fishery and defining the métiers which structure the activity of pelagic trawlers, the dynamics of this fleet are modeled using a RUM over the period 2000-2004. The capacity of the estimated model to predict the anchovy closure in year 2005 is then tested, and results are discussed.

\section{Background on the Bay of Biscay pelagic fishery}

The Bay of Biscay pelagic fleet is experiencing a severe crisis since 2005, and the closure of the anchovy fishery. This closure was adopted due to a combination of unsustainable biomass levels and poor spring anchovy recruitment in recent years, leading to concerns regarding the status of the anchovy stock. Historically, this fishery became important in the 1950's. Until 1985, the Bay of Biscay's anchovy stock was exploited by French and Spanish purse seiners in spring and during the spawning season that occurs from March to the beginning of August (with a peak in May-June). During the seventies and the early eighties the development of the pelagic fishery and the crisis in the fisheries targeting sparids led to increased anchovy fishing by this fleet (Uriarte et al. 1996).

The fishery has been managed by TAC (Total Allowable Catch) since 1978. Established at the beginning within EU waters (Divisions VIIIa, and VIIIb), the TAC has been extended to the whole Bay of Biscay (Subarea VIII) in 1986 with the inclusion of Spain in the EU. Since 1978, this TAC has 
always been set at a high level of 30-33,000 tonnes for the international fishery. It is then split between Spain (90\%) and France (10\%). Anecdotal evidence suggests that the TAC has rarely been restrictive. In addition, a bilateral agreement (the so called "Accords d'Arcachon") between France and Spain has established a level of quota exchange between France and Spain since 1992, as well as restricted fishing seasons for fleets of the two countries. As a result of this agreement the French pelagic trawler fleet is not allowed to operate in May (Uriarte et al. 1996).

Duhamel et al. (2004) describe the French fleet and its trends in term of number of vessels and vessel characteristics between 2000 and 2004, distinguishing the trawler fleet (pelagic or mixed) from purse seiners. The total fleet (vessels landing at least 1 ton of anchovy per year) went down from 146 in 2000 to 104 vessels in 2003. During that period around 75 percent of the total fleet was composed of trawlers. Most of the French anchovy pelagic trawl fleet is concentrated in the Pays de la Loire's region (Saint Nazaire and Les Sables d'Olonne harbours). The purse seine fleet is composed of vessels mainly coming from Bretagne (Le Guilvinec and Concarneau are the main ports) and Aquitaine (Bayonne) (Figure 1).

In this paper we focus on pelagic trawlers targeting anchovy. In France about 20 pairs of pelagic trawlers mainly target anchovy (Duhamel et al. 2004 and Guyader et al. 2005). Of these 20 pairs, a group of 8 (16 vessels) for which we have data during the period 2000-2005 have been identified. These vessels have shown, during this period, the same patterns in their activity, targeting mainly anchovy when they are allowed to and when it is accessible, and sea-bass, tuna or horse mackerel when it is not. Together, they represent between 25 and 30\% of the Anchovy's catches (ICES 2006) for the whole French pelagic fleet during the period 2000-2005 (Table 1). The mean length of these vessels is 20.2 meters (Standard deviation of 1.2) and the mean engine power is 373 horse power (Standard Deviation of 67). The assemblage of species and/or stock which they target is described in Table 2. The total number of trips of the selected vessels over the study period is 2518 , with a mean time of trips of 5 days at sea, which corresponds to weekly trips.

\section{Materials and methods}

\subsection{Data}

The definition of the fleet studied and its activity have been defined such that they are consistent with the recommendations from ICES (ICES 2004 and Marchal et al. 2006). We define the "fleet" as a group of vessels sharing similar characteristics in term of technical features and activity. A "métier" is then defined as fishing tactic at the scale of the trip characterized by a set of targeted species, a gear and a period of the year.

The landings and effort data used for this analysis have been derived from logbooks data registered by the French Fishery Ministry (DPMA) and extracted from "Harmonie", the database of the French Fisheries Information System managed by IFREMER. Landings and effort data were directly available from log-books and revenue/prices from sales slips. Sales slips are used to compute the mean price by month for each species caught by the fleet. These effort and landings data are available for each vessel for the whole period 2000-2005 at the scale of the trip. Each of the 2518 trips is described by 16 variables. Among the variables, 4 are discrete: year (2000-2005), month, day of the landing date that defines the week of the fishing trip and vessel number. The 11 remaining quantitative variables are the trip landings (in $\mathrm{kg}$ and the corresponding value in euros) for Anchovy Engraulis encrasicolus, Sea-Bass Dicentrarchus labrax, Tuna Thunnus alalunga, Horse Mackerel Trachurus trachurus, the sum of the other species landed and nominal effort (in hours fished).

\subsection{Métier's description}

As métiers are types of fishing trips based on landing composition in value, we consider a classification of the 2518 trips, each trip being described by the landing profile over the 4 main species and a set of other species.

We begin by providing a description of the trips based on the landings composition in value. This reflects the view that fishermen are profit maximizers, and valuable species get more weight in the analysis. The "Ward minimum variance clustering method" was used to group similar trips. In this method, the distance between two clusters is the ANOVA sum of squares between the two clusters added up over all the variables. A Hierarchical Agglomerative Clustering (HAC) analysis was used to define landings profiles.

To the best of our knowledge, there is no objective method to identify the most appropriate number of clusters, and a compromise has to be found between the number of clusters and the percentage of variance explained. First, clusters were defined at fine level and described in terms of landing profiles. 
They were then aggregated based on similarity, ensuring a reasonable balance between precision and operational requirements.

Once the number of clusters was decided, each trip was assumed to be characterized by the métier of its cluster and métiers were defined by the average landing profile of each cluster.

It is also possible that vessels stay a complete month at port (closure of the Anchovy fishery in May for the pelagic trawlers, period of inactivity at the end of the year...). To consider these periods of inactivity, a métier called "Inactivity" was attributed to each week of month without activity.

\subsection{Modeling fleet dynamics}

A discrete choice modeling framework was chosen to understand and forecast the underlying factors and mechanisms affecting the choice of métier. According to the economic theory of utility maximizing behavior, fishermen confronted with a finite set of alternatives (in this case métiers) will choose the métier that provides the highest expected utility (Wilen et al. 2002).

The period 2001-2004 was used to describe fishers' choices and find the determinants of these choices. A diversity of models were tested to find the best description of the fishery. Once the model was parameterized, its capacity to predict events such as a fishery closure was tested over the period 2005.

In discrete choice models such as the one developed here, an assumption often made in the choice of explanatory variables is that past value of key variables influences fishermen in their métier's choice, as it constitutes the basis for anticipating future prospects attached to these métiers, following an adaptive anticipation process. The practical issue is to establish the lags adequately reflecting the speed at which expectations are revised by fishermen, following changes in the values of these key variables. In some cases, a combination of seasonal effects captured by the value of these variables at the same period in the previous years, and short-term effects captured by their value in the previous days or months, is used. Various combinations of explanatory variables were tested in order to retain a formulation of the model that best fitted the 2001-2004 data. Based on the view that fishermen are profit maximizers, the model includes, but is not limited to variables that are assumed to impact expected profit. Other variables that describe fishing patterns or inertia to changes in métiers were also included in the model.

Among the different variables envisaged, some were choice-specific variables such as the fisher's fishing pattern in the previous year (12 month lag), defined as the percentage of effort in each métier in the previous year and during the same month. The fisher's fishing pattern in the previous year was initially introduced in the model because seasonal patterns are usually considered an important characteristic of fisheries, and have often been introduced as explanatory variables in RUMs, as in Holland and Sutinen (1999).

The other variables included in the analysis were individual-specific ${ }^{1}$ covariates such as the total VPUE during the previous trip. This was considered as a proxy of gross return and used as an indicator of profit ${ }^{2}$. The percentage of VPUE per species during the previous trip was also introduced in order to capture targeting behavior, reflecting the relative attractiveness of the different species. A dummy variable representing the métiers realized in the two previous trips was included to measure the short term inertia of fishing activity in terms of persistence in time of each métier, which may result from tradition, knowledge of the fishery, or fluctuations in resource abundance.

Percentage of the VPUE per species in the previous trip, the total VPUE and the "inertia" variable are individual-specific covariates. To incorporate these continuous variables in a conditional logit model, each variable was multiplied by a set of dummy variables corresponding to the different choices made during the previous trip. These dummy variables took a value of one [1] if a particular métier was actually chosen and zero [0] otherwise, with the following list of métiers: ANE for the métier targeting Anchovies, ALB for the métier targeting Tuna, BSS for the métier targeting Sea Bass, MIX for the mixed fishery and INA for the Inactivity. INA (Inactivity) was set as the reference category and all the estimated parameters were estimated relative to this category (Green 2003).

Two different conditional logit models were then tested. Model A contained the variable relative to the yearly patterns while model B did not. All the variables are described in Table 3 . These models, including models A and B described above, were tested against the hypothesis of the Independence

\footnotetext{
${ }^{1}$ Given that all vessels have experienced all of the alternatives métiers, informations were available at an individual level for all vessels and all métiers.

${ }^{2}$ The assumption here is that the cost structure of fishing is comparable across the different métiers. If this assumption, which we could not verify based on the available data, proved incorrect, our model of effort allocation should be considered as a model of gross revenue maximizing behavior.
} 
of the Irrelevant Alternative which assumes that the odds ratios in multinomial and conditional logit models for a given set of choices are independent of other alternatives which may exist (see Hausman and McFadden 1984 or Green 2003 for a description of this test). The models were assessed in terms of the percentage of correct predictions, and based on their McFadden's likelihood ratio index (LRI) (McFadden 1974), which is a coefficient analogous to $\mathrm{R}^{2}$. The only model detailed here is the selected model that best fitted the 2001-2004 data series.

The deterministic component of the indirect utility function or the expected utility function of the mixed model selected is empirically specified as follows:

$$
\begin{aligned}
& V_{i j}=\alpha_{1} * P V R T P_{3}^{*} A N E+\alpha_{2} * P V R T P_{3}^{*} B S S+\alpha_{3} * P V R T P_{3}^{*} A L B+\alpha_{4} * P V R T P_{3}^{*} M I X+
\end{aligned}
$$

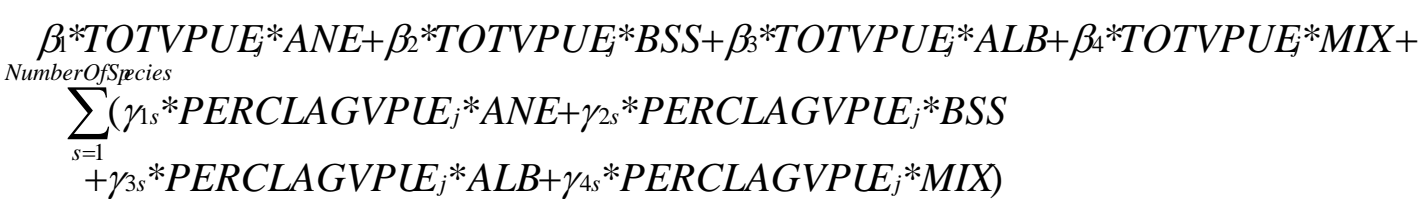

The dependent response variable Vij represents the expected utility for the $i^{\text {th }}$ trip choices (Anchovy, Horse Mackerel, Sea bass, Tuna, Mixed or No Activity) for the $j^{\text {th }}$ trip. The vectors $\alpha, \beta$ and $\gamma$ are coefficients to be estimated in the mixed model.

Once the probability of each possible choice is computed (see Equation 2), the choice actually made during the trip is defined as that with the highest probability.

$$
\operatorname{Proba}(\text { Choice }=i)_{j}=\frac{\exp \left(V_{i j}\right)}{\sum_{i=1}^{\text {NumberOfChoices }} \exp \left(V_{i j}\right)}
$$

A value of one (1) is assigned to the dependent variable if a trip of a particular type was actually chosen, and zero (0) otherwise. SAS 9.0 software was used in the model estimation (MDC procedure, SAS Institute INC. 2004).

\subsection{Capacity of the estimated model to predict the anchovy closure}

A simplified model of fleet dynamics was developed, utilizing the coefficient estimated in the above behavioral model. The model was used to simulate métiers' choices at the trip level, during the anchovy fishery closure which took place from February to May and July to December 2005. The input variables in this model were computed for the period 2001-2004 as follows. The average percentage of VPUE per species, per vessel and per trip of each month was calculated with the trips corresponding to the métier targeting Anchovy when the Anchovy fishery is opened (January and June), and without trips targeting Anchovy during the closure. The average VPUE per month and per vessel was computed in the same way.

The probability of one métier's realization for each trip was then computed by the model using the coefficients estimated by Equations 1 and 2. The variable "inertia" was computed by comparing the trip choices made during the previous two trips.

\section{Results}

\subsection{Métier's description}

Choosing 6 clusters provides a reasonable trade-off between keeping the number of clusters tractable and making use of a maximum of information available in the dataset (Figure 2). The interpretation of the dendrogram (Figure 2) was initiated using these 6 clusters. The average species composition of the 6 clusters is represented in Table 4.

Reducing the number of species implies that new clusters are aggregated by groups having the same dominant species. Despite their separation by the cluster analysis, clusters 4 and 6 seem to be quite similar with mixed landings and significant others. Considering cluster 6 , the means calculations show a quite high proportion of all species, which is characteristic of mixed fisheries. Cluster 4 is dominated by the "other species". Cluster 5 is clearly driven by horse mackerel. It would be possible to identify it as a distinct single-species métier. However considering the small number of trips finally targeting Horse Mackerel, it was not thought appropriate to integrate it in the analysis as a distinct métier. 
Finally, to restrict the number of métiers to those related to key species of interest to the fleet, clusters 4 to 6 were aggregated into one métier.

Métiers described for the fleet are then:

a métier targeting Anchovy (Cluster 1)

a métier targeting Sea Bass (Cluster 2)

a métier targeting Tuna (Cluster 3 )

a mixed métier (Cluster 4 to 6 )

The majority of trips target anchovy (Figure 3), the main species of that fishery. Métiers 1-3 are nearly exclusively single-species métiers.

\subsection{Modeling fleet dynamics}

Results of the IIA and comparison of models A and B showed that the model including the percentage of effort in the previous year and in the same month in each métier did not satisfy the IIA property (Table 5), because the statistic $\mathrm{S}$ exceeded the critical value for all deleted choices.

In the other model (without the variable corresponding to the percentage of effort in the previous year and in the same month), for all the alternatives, statistic $S$ was below the critical value except for the subset without choice 1 where the test statistic was negative. As shown by Hausman and McFadden (1984) a negative statistic is not contradictory with the IIA property. This model was thus selected.

Most coefficients in the discrete choice model were statistically significant (Table 6). The McFadden's LRI of 0.5 was equal to indicating that the model explains a substantial proportion of variation in fisher's trip choice behavior.

The coefficient PVRT, in case of positive value, indicates a tendency to keep the same métier for several trips in a row, compared to inactivity, which represents at least 4 trips in a row (4 weeks by month of inactivity). The métier targeting Sea Bass has a positive coefficient, while métiers targeting Anchovy, Tuna and mixed species have a negative coefficient. This can be interpreted as the fact that, compared to Inactivity, targeting all species for the two previous trips will reduce the probability to target the same species in the next trip, except in the case of Sea Bass. On the other hand, compared to Inactivity, the probability of targeting Sea Bass in the next trip is increased if this species was targeted during the two previous trips (Table 6).

For métiers targeting Sea Bass and Anchovy, the probability to choose this métier in the next trip increases significantly $(p=0.001)$ with the amount of Anchovy or Sea Bass respectively caught. For the mixed métier, the probability increases with the amount of Horse Mackerel and the assemblage of other species. For the métier targeting Tuna the probability of choosing this métier in the next trip is reduced (compared to inactivity) whatever the species caught in the previous trip.

For every métier, the probability to choose this métier in the next trip increases significantly $(p=0.001)$ with the total VPUE achieved during the previous trip.

The best predictions are obtained for the Anchovy métier (90 percent of the time model predicted match observed), which is the métier with the largest occurrence over 2001-2004. Fit is poorest for the Tuna métier, which is least operated over 2001-2004 (Table 7). Where the Tuna métier would be expected, the model predicts anchovy targeting which is the main métier in that period (Table 7). Over the period, the métier targeting Anchovy is slightly over-estimated (1059 trips predicted instead of 986), the métier targeting Sea Bass is relatively well estimated, and the métiers targeting Tuna and mixed species are slightly under-estimated.

Overall, however, the model offers a good fit for métiers targeting Anchovy, Sea Bass and Inactivity (Figure 4). Even if the fit is not as good for métiers targeting Tuna and the mixed fishery, the model is able to explain the seasonal peaks observed in the fleet's activity and in the associated fisheries.

\subsection{Capacity of the estimated model to predict the anchovy closure}

The results are quite similar to those obtained during the estimation period for métiers targeting Anchovy and Sea Bass, with a very high percentage of good predictions (respectively 97 and 79\%) (Table 8). The proportion of trips targeting Anchovy is quite low compared to the estimation period due to the closure of the fishery in the major part of the year. For métiers targeting Tuna and mixed species, the percentages of good predictions are higher than for the calibration period (79 and $57 \%$, compared to 8 and $37 \%$ ) and, by contrast, Inactivity has a lower percentage of good prediction (43\% compared to $80 \%)$.

Overall, predictions are reasonable for choices Anchovy, Sea Bass Tuna and the mixed fishery, but not so good for Inactivity (Figure 5). 


\section{Discussion}

In this paper, fisher's behavior in the Bay of Biscay pelagic fishery is studied by specifying and estimating a multinomial logit model. Results from this model suggest some important aspects of fisher's trip choice behavior. The degree of fit of the model is quite good during the estimation period (2001-2004) and the predictions of the closure based on this estimation can reproduce the effort reallocation of the fishery during the anchovy fishery closure in 2005. Therefore it can be used as a basis for anticipating the response of fishers to such management measures.

To our knowledge, such testing of the robustness of the model in term of predicting the observed response of a fishing fleet to a fishery closure has not been done before. Hutton et al. (2004) used the RUM to show some of the assumptions that could be expected a priori for location choice, in order to establish the assumptions and decision rules in a simulation model. However, the coefficients obtained from their Random Utility Model of effort allocation were only used indirectly in the simulation part of their study, examining the response to management rules. Holland and Sutinen (1999) used the parameters estimates with the first random quarter of the data to calculate the predicted probability for each of the 41 alternative fisheries/locations for the observations in the second quarter of the data. The results of their model were included in a simulation model to examine possible impacts of future scenarios regarding the closure of fishing areas. Pradhan and Leung (2004) suggested the use of this kind of models in a regulation context but did not apply it in their study.

Trip choices in our model are strongly influenced by the VPUE of the main species during the previous trips. This shows the high dependency of the fishery to fish availability and accessibility, which, in the case of small pelagics such as anchovy, are subject to strong spatial and temporal fluctuation. Due to these fluctuations, fishers are likely to change quickly from one métier to another.

The previous year of activity was anticipated to be an important variable for pelagic fisheries that have clear seasonal patterns. These fluctuations of the resource are also responsible for some overor under-estimation of activity for some métiers in certain months. For instance, in early 2003, fishers did not target Anchovy as they did in the other years. Hence, it appears that such fisheries can be described by a global yearly pattern but with some internal variability that is not easily captured by a variable based on the activity at the same period in the previous year. In the selected model, choices that are the most difficult to predict are trips targeting Tuna or mixed trips (respectively 8 and $37 \%$ of good prediction). Both of them are rare trips. As shown by the coefficient PVRT for Tuna and Mixed trips, vessels operating in these métiers are more susceptible to métiers shifting from one trip to another. It seems reasonable to observe that rare métiers are more difficult to predict than others. A similar observation was made in a study of the probability for fishing vessels to decommission by Thébaud et al. (2005), a relatively rare occurrence in the fleets considered in this study. The same problem could explain the increase in the prediction score in 2005 where, in proportion, Tuna trips are more frequent than during the period 2001-2004.

In the prediction model, the Inactivity choice is clearly under-estimated. Economic reasons could explain this under-estimation of Inactivity. During the anchovy closure, fishers were subsidized to stay in port. By making inactivity economically attractive, these subsidies probably influenced fisher's choices to remain inactive, more than they would have based on our estimated model of effort allocation which included zero returns for inactivity. The only way of taking this into account in the analysis would have been to give an economic value to the option of staying in port, but data were not available to do so.

This study provides some insights into the mechanisms of effort allocation following fishing bans. When a fishery is closed, the effort will be allocated to available species, especially those that are not regulated by TAC and licenses, and that allow vessels to maintain their revenue. Such behavior and its overall bio-economic implications was explored in Soulié and Thébaud (2006) from a theoretical perspective. Our study confirms the importance of including fisher responses in the assessment of the potential impacts of fishing bans ${ }^{3}$. The model could be a useful additional assessment tool to evaluate fishers' behavioral responses to management measures such as temporary anchovy harvest ban or the establishment of marine protected areas. For the fisheries in which the pelagic fleet operates, effort and landings data are available for all the main targeted species. The model could also be used to parameterize a fleet dynamics submodel in existing bio-economic simulators (e.g. ISIS-Fish

${ }^{3}$ One of the potential impacts which may be observed following short-term response of fishing effort and landings to a fishing ban is a drop in the prices of species on which effort is reallocated, due to increased landings. Such a drop was observed in 2005 for tuna landed by the pelagic fleets, and would in principle also need to be included in the analysis as a change which can be anticipated by fishermen in making their choices. 
(Mahévas and Pelletier 2004, Pelletier and Mahévas 2005, Drouineau et al. 2006), TEMAS (Ulrich et al 2002, Sparre 2003, Ulrich et al. 2007) and FLR (Kell et al. 2007)) that take into account the whole dynamics of the fishery system (biology of the targeted species, dynamics of the fishery and behavioral responses to management measure). Simulations could then be performed to provide diagnostics of the impact of management scenarios on fisheries. Further development should also include the integration in the analysis of models describing fleet behavior in the longer term, which consists of investment models describing entry/exit of vessels in the fishery.

\section{Acknowledgements}

The work was funded through the CAFE project of the European Union (DG-Fish, contract no. 022644), for which support we are very grateful.

\section{Bibliography}

Caddy, J. 1975. Spatial model for an exploited shellfish population, and its application to the Georges Bank scallop fishery. J. Fish. Res. Bd. 32: 1305-1328.

Drouineau, H., Mahévas, S., Pelletier, D. and Beliaeff, B. 2006. Assessing the impact of different managment option using ISIS-Fish: the French Merluccius merluccius - Nephrops norvegicus fishery of the Bay of Biscay. Aquat. Living Resour. 19: 15-29.

Duhamel, E., Biseau, A. and Massé, J. 2004. The French anchovy fishery. Working Document to the Working Group on the Assessment of Mackerel, Horse Makerel, Sardine and Anchovy. ICES CM 2005/ACFM:08.

Green, W. 2003. Econometric Analysis. Fifth Edition, Prentice Hall: Englewood Cliffs.

Guyader, O., Daurès, F., Thébaud, O., Leblond, E. and Demaneche, S. 2005. "The French anchovy fishing fleet - Area VIII. Structure, recent trends and preliminary analysis of the potential impact of a fishery ban on the fishing fleets". Scientific, Technical and Economic Committee for Fisheries Working Group Anchovy, Brussels, 11-13 July 2005.

Hausman, J. and McFadden, D. 1984. Specification Tests for the Multinomial Logit Model. Econometrica 52 (5): 1219-1240

Hilborn, R. 1985. Fleet dynamics and individual variation: why some people catch more than others. Can. J. Fish. Aquat. Sci. 42: 2-13.

Holland, D.S. and Sutinen J. G. 1999. An empirical model of fleet dynamics in New England trawl fisheries. Can. J. Fish. Aquat. Sci. 56: 253-264.

Hutton, T., Mardle, S., Pascoe, S. and Clark, R.A. 2004. Modelling fishing location choice within mixed fisheries: English North Sea beam trawlers in 2000 and 2001. ICES J. Mar. Sci. 61:14431452.

ICES 2004. Report of the Study Group on the Development of Fishery-Based Forecasts. ICES CM 2004/ACFM:11, $37 \mathrm{pp}$.

ICES 2006. Report of the Working Group on the Assessment of Mackerel, Horse Mackerel, Sardine and Anchovy. ICES CM 2006/ACFM:36.

Kell, L., Mosqueira, I., Grosjean, P., Fromentin, J., Garcia, D., Hillary, R., Jardim, E., Mardle, S., Pastoors, M., Poos, J., Scott, F. and Scott, R. 2007. FLR: an open-source framework for the evaluation and development of management strategies. ICES J. Mar. Sci. 64: 640-646.

Mahévas, S. and Pelletier, D. 2004. ISIS-Fish, a generic and spatially-explicit simulation tool for evaluating the impact of management measures on fisheries dynamics. Ecol. Model. 171: 65-84.

Marchal, P., Andersen, B.S., Bromley, D., Iriondo, A., Mahévas, S., Quirijns, F., Rackham, B., Santurtún, M., Tien, N. and Ulrich, C. 2006. Improving the definition of fishing effort for important European fleets by accounting for the skipper effect. Can. J. Fish. Aquat. Sci. 63: 510-533.

McFadden, D. 1974. The measurement of urban travel demand. Journal of Public Economics. 3 (4): 303-328.

Pelletier, D. and Mahévas, S. 2005. Fisheries simulation models for evaluating the impact of management policies, with emphasis on marine protected areas. Fish Fish. 6(4): 307-349.

Pradhan, N. and Leung, P. 2004. Modeling trip choice behavior of the longline fishers in Hawaii. Fish. Res. 68: 209-224.

Prellezo, R., Andersen, B.S., Guyader, O., Hutton, T., Marchal, P., Mardle, S. and Thébaud, O. 2006. Explaining short-term choice through random utility models. 12 pages. In: Proceedings of the 
Thirteenth Biennial Conference of the International Institute of Fisheries Economics \& Trade, July 11-14, 2006, Portsmouth, UK: Rebuilding Fisheries in an Uncertain Environment. Compiled by Ann L. Shriver. International Institute of Fisheries Economics \& Trade, Corvallis, Oregon, USA, 2006.

SAS Institute Inc. 2004. SAS/ETS 9.1 User's Guide, SAS Institute Inc., Cary, NC, USA.

Sala, S. and Gaertner, D. 2004. The behavioural dynamics of fishers: management implications. Fish Fish. 5: 153-167.

Smith, M.D. and Wilen, J.E. 2003. Economic impacts of marine reserves: the importance of spatial behavior. J. Environ. Econom. Management 46, (2): 183-206.

Sparre, P.J. 2003. An EXCEL-based software toolbox for stochastic fleet-based forecast. ICES Document CM 2003/V: 07.

Soulié J.C., O. Thébaud, 2006. 'Modelling fleet response in regulated fisheries: an agent-based approach'. Mathematical and computer modelling 44: 553-564.

Thébaud, O., Daurès, F., Guyader, O., Travers, M. and Van Iseghem, S. 2005. 'Modelling the adjustment of fishing fleets to regulatory controls: the case of South-Brittany trawlers (France), 1990-2003'. AMURE (AMénagement des Usages des Ressources et des Ecosystèmes marins et littoraux) Working Paper D13-2006, Brest.

Ulrich, C., Andersen, B.S., Sparre, P.J. and Nielsen, J.R. 2007. TEMAS: fleet-based bio-economic simulation software to evaluate management strategies acounting for fleet behaviour. ICES J. Mar. Sci. 64, (4). 6447-6651.

Ulrich, C., Pascoe, S., Sparre, P., De Wilde, J. and Marchal, P. 2002. Influence of trends in fishing power on bioeconomics in the North Sea flatfish fishery regulated by catches or by effort quotas. Can. J. Fish. Aquat. Sci. 59: 829-843.

Uriarte, A., Prouzet P. and Villamor, B. 1996. Bay of Biscay and Ibero Atlantic anchovy populations and their fisheries. Sci. Mar. 60:237-255.

Wilen, J., Smith, M., Lockwood, D. and Botsford, L. 2002. Avoiding surprises: incorporating fisherman behavior into management models. Bull. Mar. Sci. 70(2): 553-575. 
Tables

Table 1 Total French and studied pair trawlers annual catches and corresponding percentage total catches from 2000 to 2005

\begin{tabular}{cccc}
\hline year & $\begin{array}{c}\text { French annual Anchovy's catches (in Annual Anchovy's } \\
\text { tonnes) as estimated by the ICES } \\
\text { working group members }\end{array}$ & $\begin{array}{c}\text { corresponding } \\
\text { catches of the pair } \\
\text { trawlers in study }\end{array}$ & $\begin{array}{c}\text { percentage total } \\
\text { catches }\end{array}$ \\
\hline 2000 & 17765 & 4638 & 26 \\
2001 & 17087 & 4296 & 25 \\
2002 & 10988 & 3568 & 32 \\
2003 & 7593 & 2266 & 30 \\
2004 & 8781 & 2522 & 29 \\
2005 & 952 & 254 & 27 \\
\hline
\end{tabular}

Table 2 Share of the different species in the total landings of the fleet during the period 2000-2005

\begin{tabular}{ccc}
\hline specie & $\begin{array}{c}\text { Total of the catches (in tonnes) over the } \\
\text { period 2000-2005 }\end{array}$ & percentage \\
\hline \hline Anchovy & 17544 & 76.5 \\
Sea-Bass & 1555 & 6.8 \\
Tuna & 1285 & 5.6 \\
Horse Mackerel & 1179 & 5.1 \\
Mackerel & 542 & 2.4 \\
Hake & 110 & 0.5 \\
Sardine & 93 & 0.4 \\
Others & 611 & 2.2 \\
\hline
\end{tabular}

Table 3. Definition of the variables used in the Random Utility Models (RUM)

\begin{tabular}{ll}
\hline Variables & Definition \\
\hline PERC_LAGPERIODY & $\begin{array}{l}\text { Percentage of the effort spent in the métier the current month, the previous } \\
\text { year }\end{array}$ \\
PERC_LAG_VPUES & $\begin{array}{l}\text { Percentage of the VPUE realized in the species during the previous trip } \\
\text { TOT_VPUE }\end{array}$ \\
PVTRP & $\begin{array}{l}\text { Total VPUE realized the previous trip } \\
\text { Inertiammy equal to } 1 \text { if two previous trip is equal to the trip before, } 0\end{array}$ \\
ANE & Trip dummy equal to 1 if the chosen trip is targeting Anchovy, 0 otherwise \\
ALB & Trip dummy equal to 1 if the chosen trip is targeting Tuna, 0 otherwise \\
BSS & Trip dummy equal to 1 if the chosen trip is targeting Sea Bass 0 otherwise \\
MIX & $\begin{array}{l}\text { Trip dummy equal to } 1 \text { if the chosen trip is Mixed species métier, } 0 \\
\text { otherwise }\end{array}$
\end{tabular}


Table 4. Mean percentage in value per species and per cluster

\begin{tabular}{ccccccc}
\hline \multirow{2}{*}{ CLUSTER } & \multirow{2}{*}{$\begin{array}{c}\text { Number of } \\
\text { observations }\end{array}$} & Tuna & Anchovy & Sea-Bass & Others & $\begin{array}{c}\text { Horse } \\
\text { Mackerel }\end{array}$ \\
\hline 1 & 1292 & 0.1 & 99.1 & 0.3 & 0.2 & 0.4 \\
2 & 420 & 0.00 & 0.2 & 96.9 & 2.5 & 0.4 \\
3 & 106 & 90.2 & 0.5 & 0.00 & 8.8 & 0.5 \\
4 & 146 & 1.4 & 0.2 & 2.8 & 91.9 & 0.37 \\
5 & 80 & 0.6 & 0.1 & 2.5 & 2.4 & 94.3 \\
6 & 126 & 2.0 & 18.7 & 33.6 & 27.1 & 18.6 \\
\hline
\end{tabular}

Table 5. Test statistics for the IIA property

Model A

Model B

\begin{tabular}{ccccc}
\hline Deleted choice & Statistic S & P-value & Statistic S & P-value \\
\hline 4 & 110.48 & $<0.0001$ & 8.33 & 0.99 \\
3 & 364 & $<0.0001$ & 29.39 & 0.1 \\
2 & 123.95 & $<0.0001$ & 6.88 & 0.99 \\
1 & 460.1 & $<0.0001$ & Negative & \\
\hline Degree of & \multicolumn{3}{c}{21} \\
freedom & \multirow{2}{*}{22} & \multicolumn{2}{c}{38.93} \\
$\begin{array}{c}\text { Critical chi- } \\
\text { squared[df] }\end{array}$ & \multicolumn{2}{c}{30.29} & & \\
\hline
\end{tabular}

Model A: Model including the percentage of effort per month the previous year Model B: Model not including the variable percentage of effort per month the previous year

Table 6. Parameter estimates from the discrete choice model on trip choice behavior

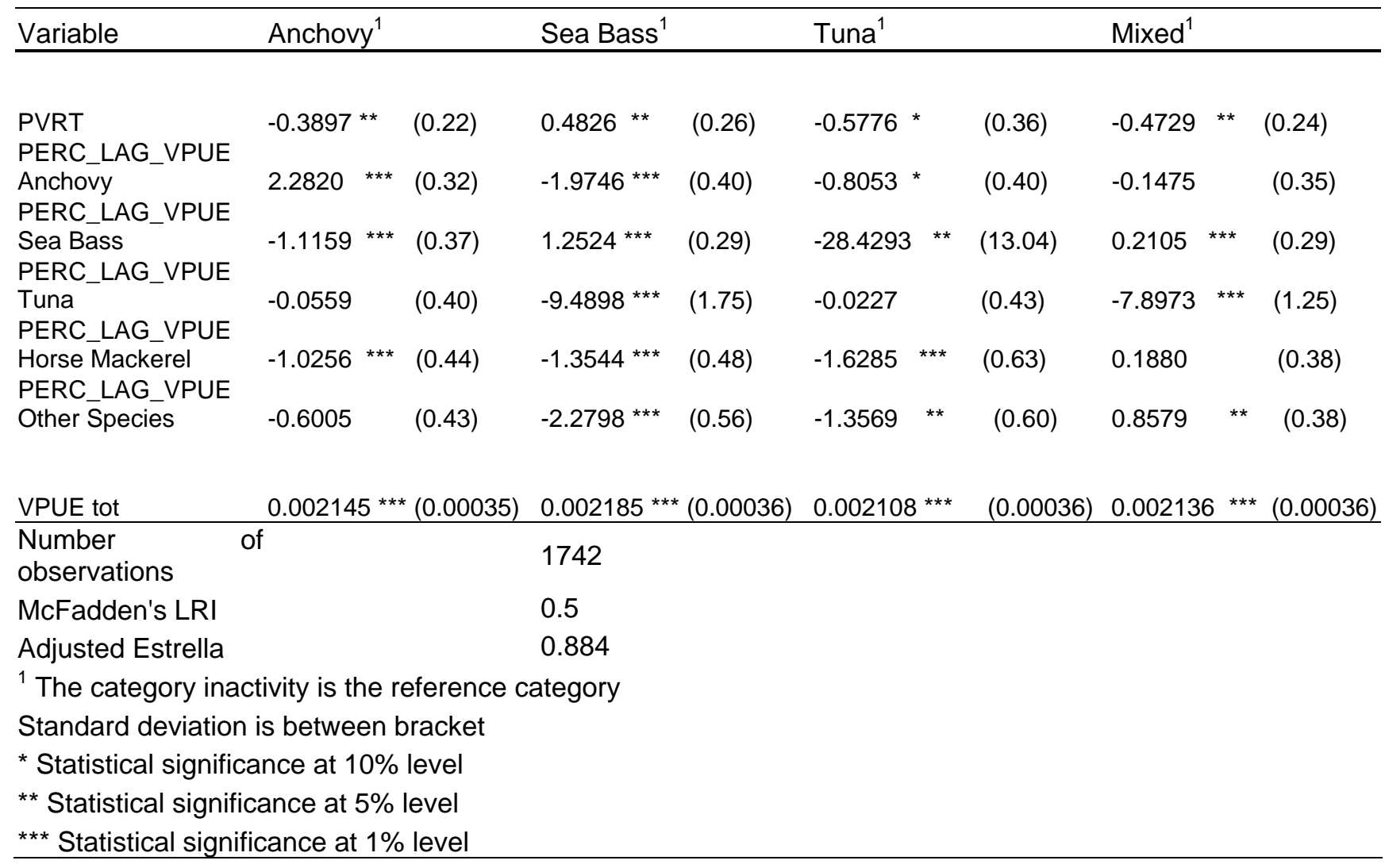


Table 7. Correspondences between predicted and observed choices (2001-2004)

\begin{tabular}{|c|c|c|c|c|c|c|c|}
\hline & \multicolumn{7}{|c|}{ Observed choices } \\
\hline \multirow{7}{*}{ 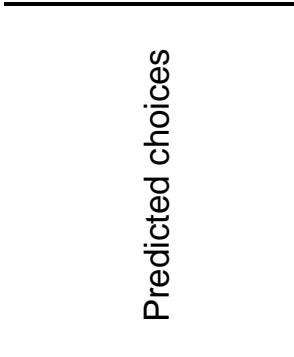 } & & 1 & 2 & 3 & 4 & 5 & sum \\
\hline & 1 & 878 & 32 & 47 & 83 & 19 & 1059 \\
\hline & 2 & 23 & 178 & 0 & 51 & 16 & 268 \\
\hline & 3 & 8 & 0 & 5 & 0 & 0 & 13 \\
\hline & 4 & 40 & 27 & 8 & 86 & 8 & 169 \\
\hline & 5 & 37 & 11 & 7 & 9 & 169 & 233 \\
\hline & sum & 986 & 248 & 67 & 229 & 212 & 1742 \\
\hline $\begin{array}{l}\text { Percentage times } \\
\text { that observed } \\
\text { matches predicted }\end{array}$ & & 90 & 72 & 8 & 37 & 80 & 76 \\
\hline
\end{tabular}

Table 8. Comparison of the predicted and observed choices in 2005

\begin{tabular}{|c|c|c|c|c|c|c|c|}
\hline \multirow{8}{*}{ 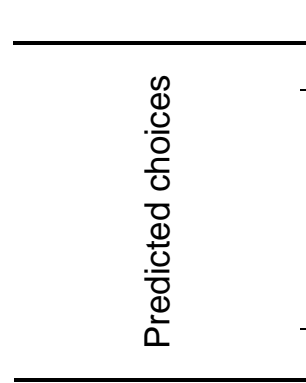 } & \multicolumn{7}{|c|}{ Observed choices } \\
\hline & & 1 & 2 & 3 & 4 & 5 & sum \\
\hline & 1 & 56 & 12 & 0 & 5 & 0 & 73 \\
\hline & 2 & 2 & 95 & 0 & 11 & 16 & 124 \\
\hline & 3 & 0 & 1 & 23 & 6 & 8 & 38 \\
\hline & 4 & 0 & 8 & 0 & 45 & 12 & 65 \\
\hline & 5 & 0 & 4 & 6 & 11 & 28 & 49 \\
\hline & sum & 58 & 120 & 29 & 78 & 64 & 349 \\
\hline $\begin{array}{l}\text { Percentage times } \\
\text { that observed } \\
\text { matches } \\
\text { predicted }\end{array}$ & & 97 & 79 & 79 & 58 & 44 & 76 \\
\hline
\end{tabular}

\section{Figures}

Figure 1. ICES divisions and main French regions and harbors for the French anchovy fleets

Figure 2. Dendrogram and number of the clusters

Figure 3. Total catches per species and per métiers (in million $\mathrm{kg}$ ) during the period 2000-2005 and corresponding number of trips

Figure 4. Comparison between predicted and observed number of trips per métier during the period 2001-2004 (Observed in continuous and predicted in dashed lines). Métier targeting (1) anchovy, (2) sea bass, (3) tuna, (4) mixed and (5) Inactivity.

Figure 5. Comparison between predicted and observed number of trips per métier in 2005 (Observed in continuous and predicted in dashed lines). Métier targeting (1) anchovy, (2) sea bass, (3) tuna, (4) mixed and (5) Inactivity. 


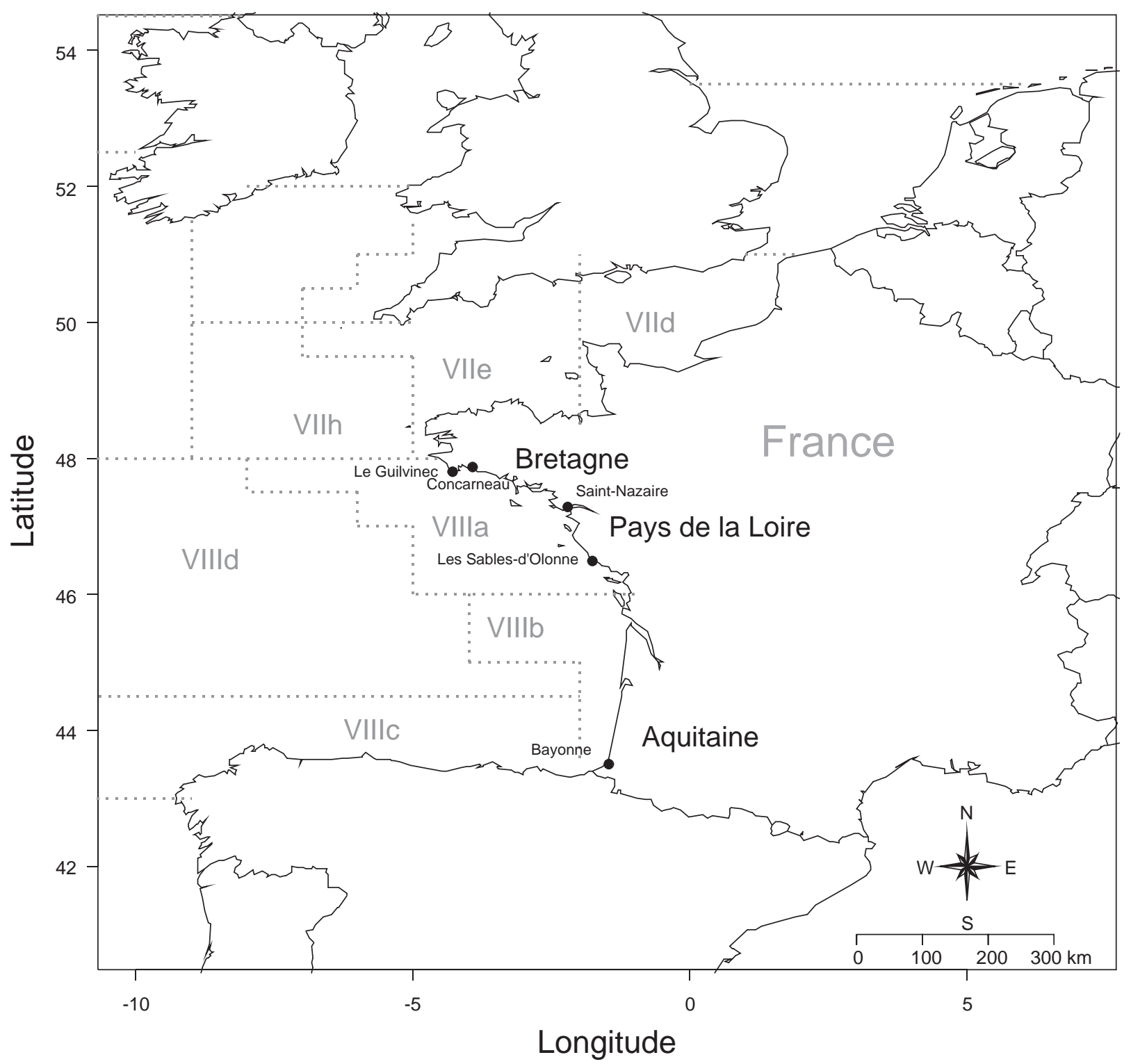




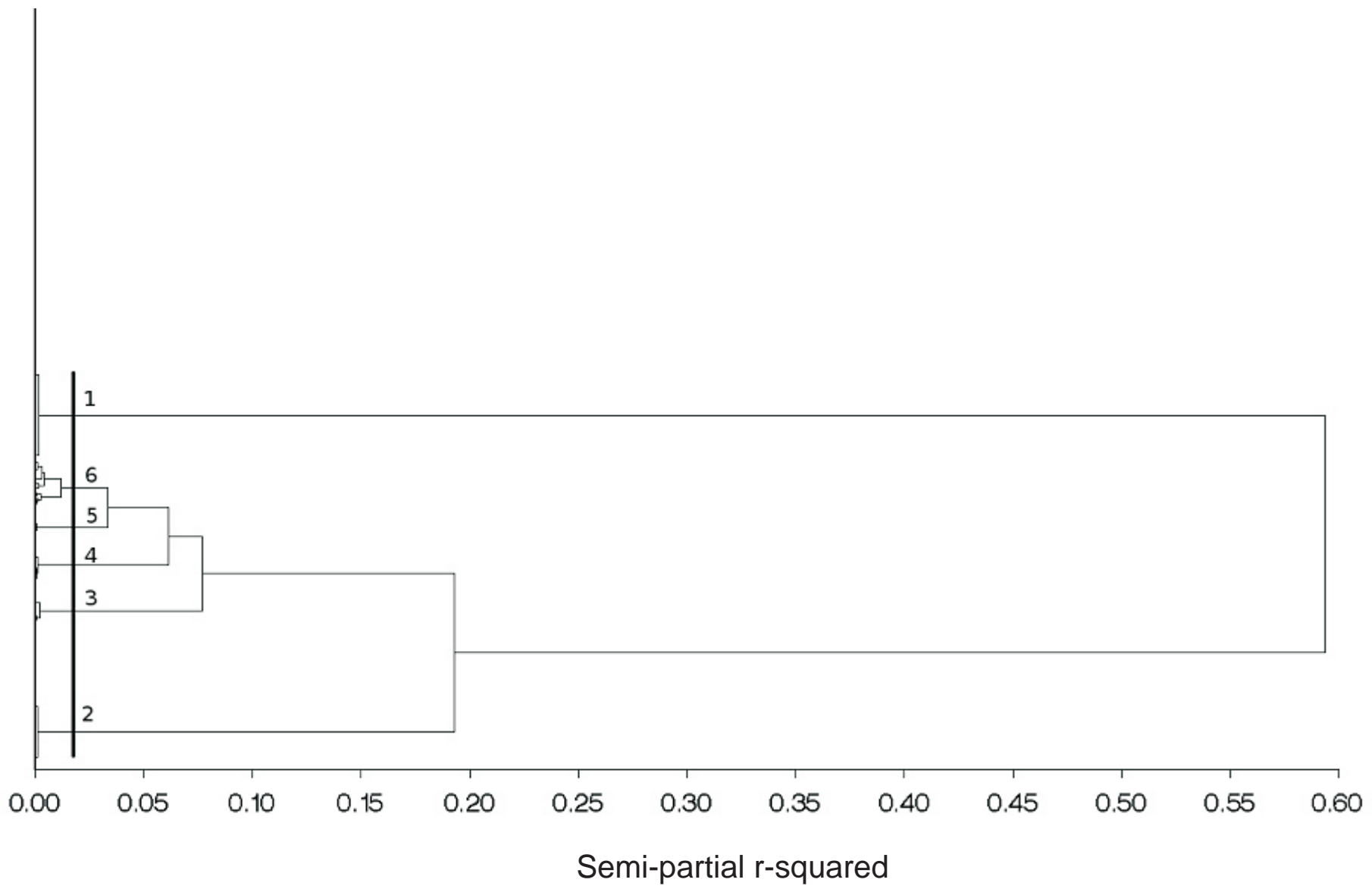




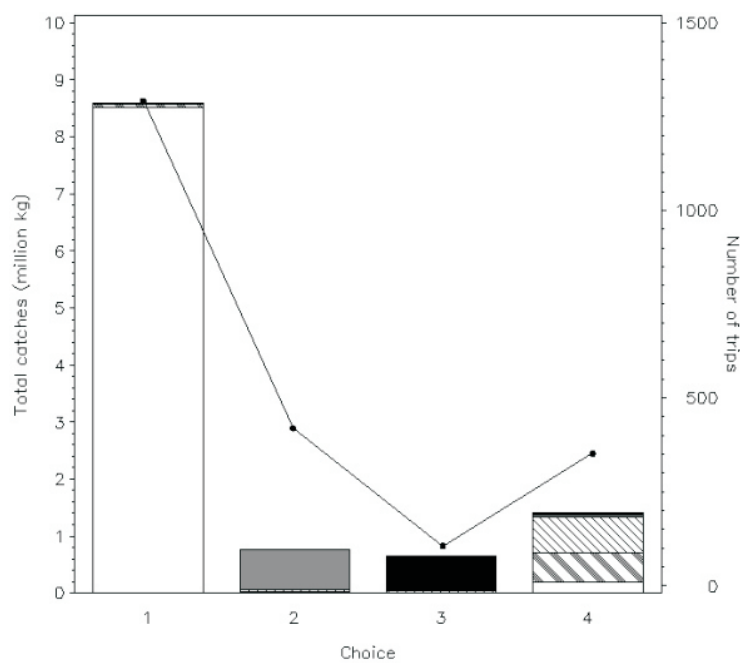

Species Anchovy $\begin{aligned} & \text { Anorse mackerel } \\ & \text { Sea boss }\end{aligned}$ 

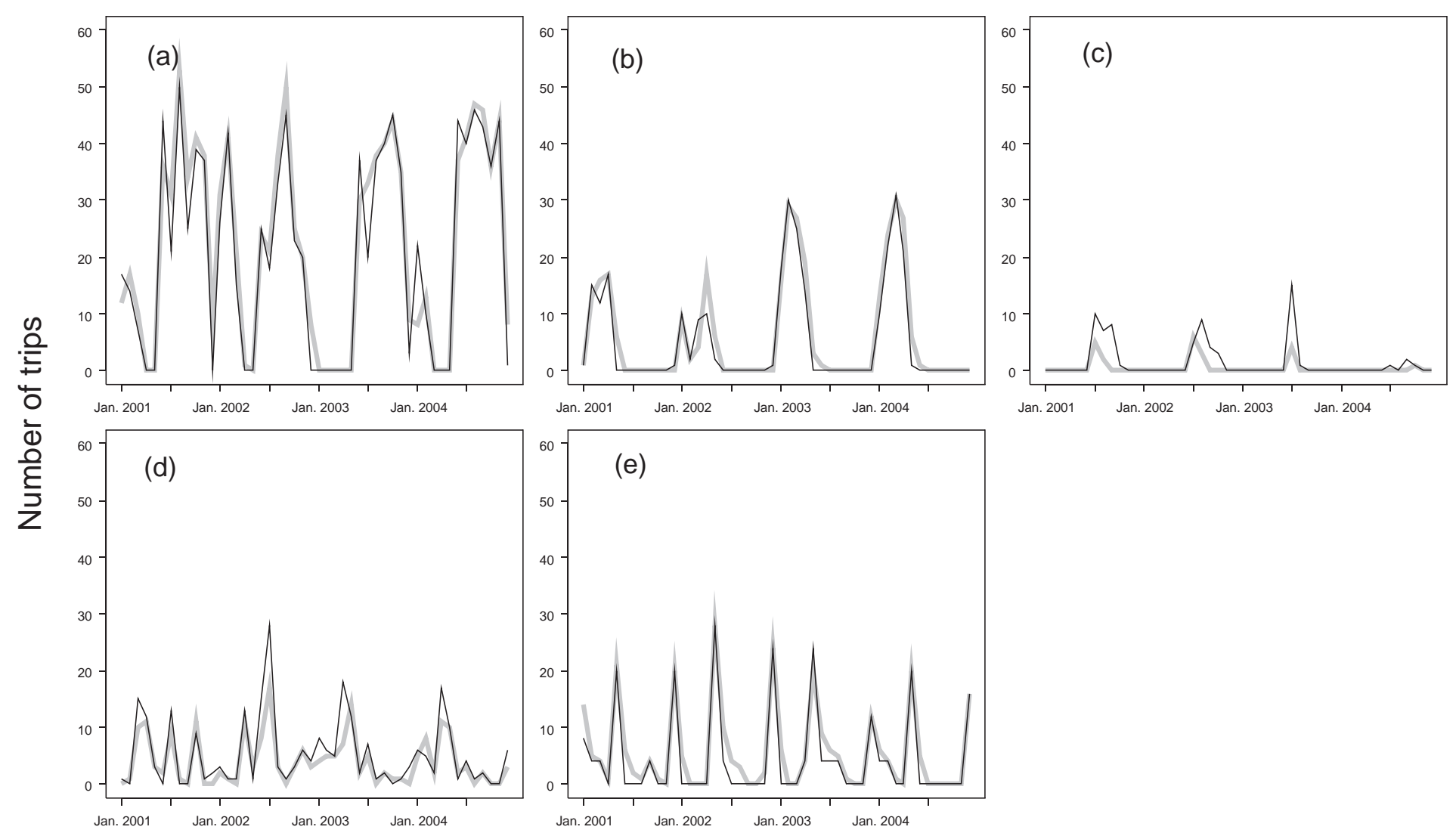

Time period 

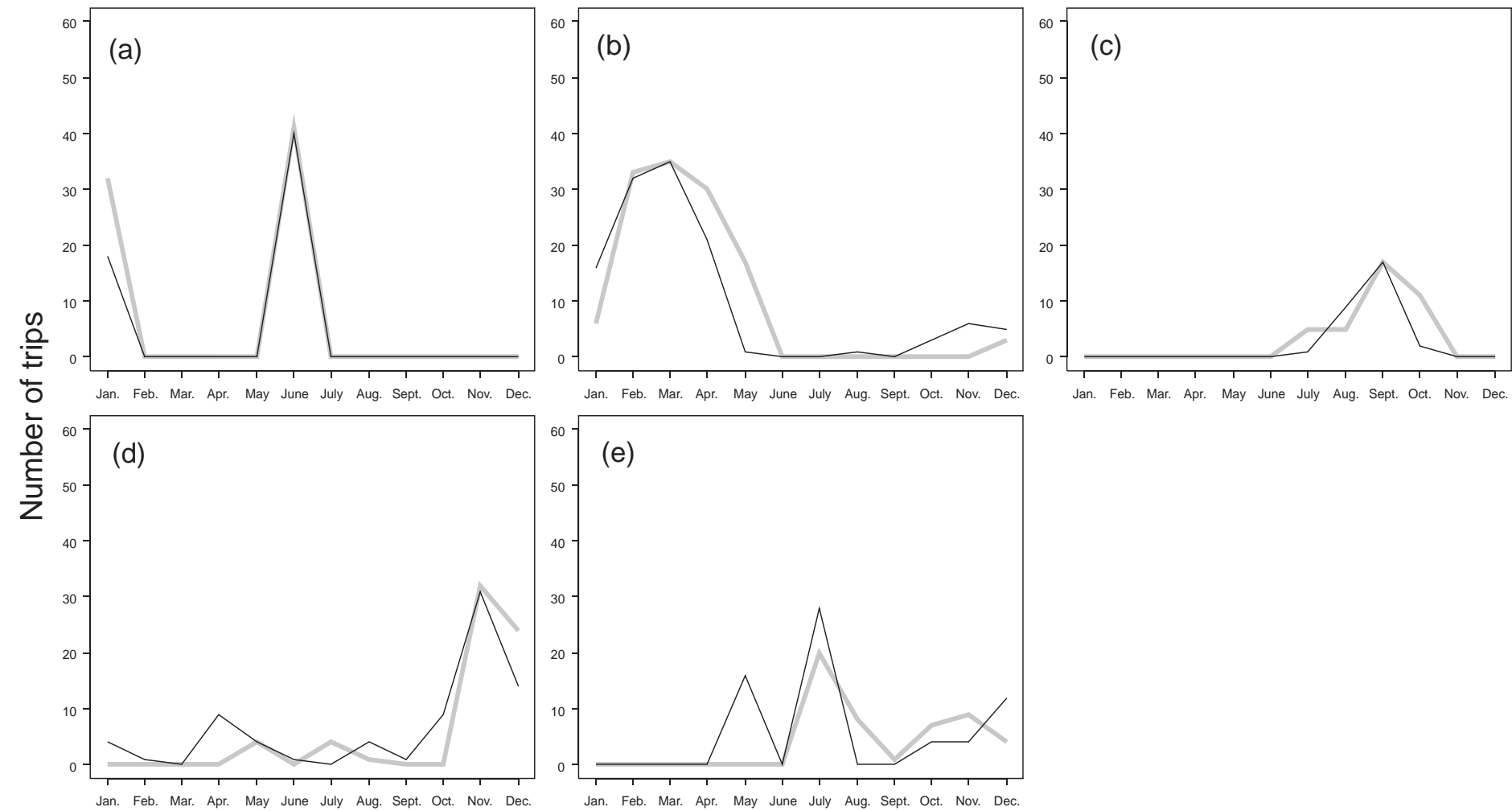

Month in 2005 